\title{
Effect of Renibacterium salmoninarum levels in the ovarian fluid of spawning chinook salmon on the prevalence of the pathogen in their eggs and progeny
}

\author{
Ernie G. H. Lee ${ }^{1}$, T. P. T. Evelyn ${ }^{2}$ \\ 'British Columbia Research Corporation, 3650 Wesbrook Mall, Vancouver, British Columbia, Canada V6S 2L2 \\ ${ }^{2}$ Department of Fisheries and Oceans, Biological Sciences Branch, Pacific Biological Station, Nanaimo, British Columbia, \\ Canada V9R $5 \mathrm{~K} 6$
}

\begin{abstract}
Chinook salmon, Oncorhynchus tshawytscha, eggs were exposed to ovarian fluid inoculated with various concentrations of Renibacterium salmoninarum (Rs), the causative agent of bacterial kidney disease of salmonids, in an attempt to infect them. None of the eggs exposed to $1.7 \times 10^{3}$ or fewer Rs cells $\mathrm{ml}^{-1}$ of ovarian fluid proved to be infected intraovum. However, intraovum infections occurred in eggs exposed to Rs cells at concentrations of $1.7 \times 10^{5}$ or higher $\mathrm{ml}^{-1}$. Smolts derived from eggs exposed to Rs cells at concentrations of $1.7 \times 10^{3}$ and higher were Rs-infected. As with eggs, the highest prevalence of infection in smolts occurred in those derived from eggs exposed to the highest concentration of Rs tested. In addition, smolts derived from eggs that were not deliberately exposed to Rs, but which were obtained from ovarian fluid naturally infected with as few as 28 to 113 Rs cells $\mathrm{ml}^{-1}$, were also infected. The implications of these findings are discussed.
\end{abstract}

\section{INTRODUCTION}

Bacterial kidney disease (BKD) is an importani chronic disease of wild and propagated salmonids. The disease can be transmitted horizontally (Mitchum \& Sherman 1981, Bell et al. 1984) as well as vertically (Bullock et al. 1978, Evelyn et al. 1986a). Vertical transmission of the causative bacterium Renibacterium salmoninarum (Rs) is mediated by the intraovum bacterium (Evelyn et al. 1984a, b, Lee \& Gordon 1987a), and ovarian fluid has been implicated as an important source of infection for eggs (Evelyn et al. 1986a).

In an effort to minimize vertical transmission of Rs, salmon farmers in British Columbia (B.C.) have undertaken costly broodstock screening programs to identify and avoid Rs-infected females that might yield infected eggs (Lee 1986, Lee and Gordon 1987a). Screening was accomplished by examining ovarian fluid for the presence of Rs using the indirect fluorescent antibody technique (IFAT) and culture. Eggs taken from fish found to be infected were destroyed. Unfortunately, the screening program appears not to have worked. The scrrening procedures, as applied, often resulted in contractictory results (Armstrong et al. in press), making it difficult to decide which batches of eggs were safe and suggesting that many Rs-infected eggs may have been passed as acceptable.

Recently, Elliott \& Barila (1987) developed a membrane filtration-fluorescent antibody technique for detecting and quantifying Rs cells in ovarian fluid. The method proved very sensitive, and a modified version of it - the membrane filtration-indirect fluorescent antibody technique (MF-IFAT) (Lee \& Gordon 1987b) was successfully used for investigating the numbers of Rs cells in ovarian fluid. The results indicated that the numbers of Rs cells found in ovarian fluid using MFIFAT were dramatically higher than those found using conventional methods of culture or IFAT. The MF-IFAT was therefore used in the present study, the objective of which was to determine the effect of Rs cell numbers in ovarian fluid of chinook salmon, Oncorhynchus tshawytscha, on the prevalence of Rs infections in their eggs and progeny. 


\section{MATERIALS AND METHODS}

Source of eggs and milt. Approximately 5000 eggs were collected from 10 apparently healthy chinook salmon that had returned from the sea to spawn at Robertson Creek Hatchery, Vancouver Island, B.C. The eggs from each fish were collected in clean, separate containers (500 per container) and were kept on ice until needed. Milt from 3 apparently healthy chinook salmon was also collected at this hatchery and stored on ice until required.

General. Eggs were used in 2 experiments immediately on their arrival in the laboratory (within $6 \mathrm{~h}$ of collection). In the first experiment, equal portions of eggs from Spawners 1 to 5 and Spawners 6 to 10 were pooled to torm 2 egg lots: Lots 1 and 11 , respectuvely. Groups of eggs from these lots were exposed to various concentrations of Rs cells to determine what effect this would have on the prevalence of infection in eggs and the progeny derived from these eggs. In the second experiment, eggs remaining from Spawners 1 to 5 were processed separately, and without exposure to Rs, to permit observations on the prevalence of background Rs infection conferred on young fish by individual spawners. Eggs from Spawners 6 to 10 were not processed in this manner due to a shortage of egg incubation trays.

Expt 1. Egg infection protocol: Egg infections were accomplished by immersing soft (non-water-hardened) eggs in ovarian fluid containing various concentrations of Rs cells: 0 (control group), $1.7 \times 10^{3}, 1.7 \times 10^{5}, 1.7 \times$ $10^{7}$, or $1.7 \times 10^{9}$ Rs cells ml ${ }^{-1}$ From each of the 2 lots of pooled eggs, groups of ca 500 eggs were immersed in $25 \mathrm{ml}$ of ovarian fluid containing one or the other of the above Rs cell concentrations. The exposure was conducted at 4 to $5^{\circ} \mathrm{C}$ in cotton-stoppered 1 l Erlenmever flasks for $12 \mathrm{~h}$, the flasks being rotated slowly (30 to $40 \mathrm{rpm}$ ) on a Labline Orbit Shaker.

Ovarian fluid used for egg exposures was freed of particulate material (host cells, tissue debris, bacteria) by centrifugation $(3000 \times g$ for $10 \mathrm{~min}$ ) and by passage through a 0.45 um pore diameter filter (Naigene sterilization filter unit, Type $S_{;}$Sybron/Nalge, Rochester, $N Y)$. The clarified fluid was then inoculated with sufficient Rs cells to achieve the Rs cell concentrations mentioned. The Rs cells used in the egg exposures (Rs Isolate 384; Evelyn et al. 1986a) were grown on KDM2 (Evelyn 1977) for $14 \mathrm{~d}$ at $15^{\circ} \mathrm{C}$ and were suspended in phosphate buffered saline ( $\mathrm{pH}$ 7.2) to give a Rs cell count of $1.7 \times 10^{10} \mathrm{ml}^{-1}$ using MF-IFAT. This suspension was appropriately diluted with sterile, clarified ovarian fluid to give the desired egg challenge suspensions. Homogeneous distribution of Rs cells in the suspensions was achieved by repeated trituration using a $3 \mathrm{ml}$ syringe fitted with a 22 gauge 1 ini. hypodermic needle.
Detection of intra-ovum Rs infections: Following the challenge of eggs, they were immediately dry-fertilized with milt pooled from 3 apparentiy healthy chinook salmon, the kidneys of which proved Rs-free on the basis of (IFAT). Eggs were then rinsed free of milt with several changes of dechlorinated Vancouver City water $\left(4^{\circ} \mathrm{C}\right)$ and surface-disinfected for $15 \mathrm{~min}$ with $500 \mathrm{ppm}$ iodine (supplied as Ovadine ${ }^{\mathbb{B}}$ ). Duplicate groups (100 eggs group ${ }^{-1}$ ) of eggs from each lot and from each challenge treatment were then tested for the presence of intra-ovum Rs. In this test, eggs were incubated in KDM2 broth ( 1 egg per tube of $5 \mathrm{ml}$ broth) at $15^{\circ} \mathrm{C}$ for 2 mo to enrich the numbers of any intraovum Rs cells present (Evelyn et al. 1984b). An egg was considered surface-sterile (and fit, therefore, for intraovum sampingi if the broth surrounding it remained clear and if no Rs cells were found in the broth using MF-IFAT

To detect Rs cells within eggs, the contents of those eggs shown to be surface-sterile were aseptically removed (Lee \& Gordon 1987a). For any given challenge treatment, the egg contents were pooled (10 eggs pool ${ }^{-1}$, or in a few instances 5 to 14 eggs pool ${ }^{-1}$ ). The pooled samples were each centrifuged $(3000 \times g$ for 10 min) to yield a pellet from which a smear was prepared for examination by IFAT Fifty microscopic fielcts per smuar were read (magnification -1000 ). Details of the egg content screening procedure are given in Lee \& Gordon (1987a). The egg content pellets were also cultured for Rs on $\mathrm{KDM} 2$ (at $15^{\circ} \mathrm{C}$ for $4 \mathrm{wk}$ )

Surface-disinfected eggs from the variously challenged groups that were not sampled for intra-ovum Rs were incubated, according to the treatment received, in separate Heath trays. Trays were supplied with dechlorinated Vancouver City water at 4 to $8^{\circ} \mathrm{C}$, the dechlorination having been accomplished in our laboratory, just prior to use. On hatching, the resultant fry were immediately transferred to 1000 l tanks, 1 treatment tank ${ }^{-1}$, where they were raised to the smolt stage on a dry, pelletted, commercial ration in the same water supply $\left(8\right.$ to $15^{\circ} \mathrm{C}$ ). (The above water supply was used to reduce the likelihood that Rs infections would be introduced with the water.) At this stage (195 d posthatching), 100 smolts (4.45 $\mathrm{g}$ a piece) from each treatment group were collected at random and examined for Rs to determine whether vertical transmission had occurred (MF-IFAT, Lee 1989). In the procedure, kidney tissue samples were homogenized in peptone $(0.1 \%)$ - saline $10.85 \% \mathrm{NaCl})$ using a stomacher. The suspensions were then filtered $(5 \mathrm{\mu m}$ pore diameter filter) and trypsinized to facilitate their examination by MF-IFAT. Fifty microscopic fields (magnification = 1000) were examined per kidney sample.

Expt 2. Approximately 150 eggs, retained from each of Spawners 1 to 5 , were dry-fertilized with the same 
batch of milt used in the first experiment. Eggs were then rinsed free of milt and surface-disinfected as already described. They were then incubated, according to spawner, in separate Heath trays until hatching. Resultant fry were immediately transferred to 200 l tanks (progeny of 1 spawner $\tan \mathrm{k}^{-1}$ ) where they were reared to the smolt stage. At this stage, 100 smolts were collected at random and their kidneys examined for Rs - to determine whether vertical transmission had occurred. The egg incubation and fry rearing conditions, the timing of smolt sampling, and the procedure used for detecting Rs in smolts were the same as those already described in connection with Rs-challenged eggs.

\section{RESULTS AND DISCUSSION}

Table 1 presents results of the efficacy of the egg surface disinfection procedure. Among the 20 groups of

Table 1. Renibacterium salmoninarum. Efficacy of surface disinfection of eggs exposed to various concentrations of Rs in ovarian fluid. Unfertilized non-water-hardened eggs were challenged at 4 to $5^{\circ} \mathrm{C}$ by immersing them for $12 \mathrm{~h}$ under continuous shaking at 30 to $40 \mathrm{rpm}$ in ovarian fluid inoculated with various dosages of viable Rs cells. Eggs were fertilized with fresh milt pooled from 3 healthy males. Prior to incubation in $\mathrm{KDM} 2$ broth at $15^{\circ} \mathrm{C}$, fertilized eggs were rinsed with water and surface-disinfected by immersion for $15 \mathrm{~min}$ in $500 \mathrm{ppm}$ iodine (Ovadine ${ }^{5}$. Egg survival: no. disinfected eggs with surviving surface-borne bacteria or Rs cells per 100 eggs tested; Sterile: \% eggs found surfacesterile

\begin{tabular}{|c|c|c|c|c|c|}
\hline \multirow[t]{2}{*}{ Rs cells $\mathrm{m}^{-1}$} & \multirow[t]{2}{*}{ Lot } & \multirow[t]{2}{*}{ Replicate } & \multicolumn{2}{|c|}{ Egg survival } & \multirow[t]{2}{*}{ Sterile } \\
\hline & & & $\begin{array}{l}\text { Bac- } \\
\text { teria }\end{array}$ & $\begin{array}{l}\text { Rs } \\
\text { cells }\end{array}$ & \\
\hline 0 & I & 1 & 8 & 0 & 92 \\
\hline 0 & & 2 & 11 & 0 & 89 \\
\hline 0 & II & 1 & 7 & 0 & 93 \\
\hline 0 & & 2 & 5 & 0 & 95 \\
\hline $1.7 \times 10^{3}$ & I & 1 & 10 & 0 & 90 \\
\hline $1.7 \times 10^{3}$ & & 2 & 11 & 0 & 89 \\
\hline $1.7 \times 10^{3}$ & II & 1 & 12 & 0 & 88 \\
\hline $1.7 \times 10^{3}$ & & 2 & 15 & 0 & 85 \\
\hline $1.7 \times 10^{5}$ & [ & 1 & 9 & 0 & 91 \\
\hline $1.7 \times 10^{5}$ & & 2 & 16 & 0 & 84 \\
\hline $1.7 \times 10^{5}$ & II & 1 & 7 & 0 & 93 \\
\hline $1.7 \times 10^{5}$ & & 2 & 13 & 0 & 87 \\
\hline $1.7 \times 10^{7}$ & I & 1 & 8 & 0 & 92 \\
\hline $1.7 \times 10^{7}$ & & 2 & 12 & 0 & 88 \\
\hline $1.7 \times 10^{7}$ & II & 1 & 11 & 0 & 89 \\
\hline $1.7 \times 10^{7}$ & & 2 & 9 & 0 & 91 \\
\hline $1.7 \times 10^{9}$ & I & 1 & 14 & 0 & 86 \\
\hline $1.7 \times 10^{3}$ & & 2 & 9 & 0 & 91 \\
\hline $1.7 \times 10^{9}$ & II & 1 & 7 & 0 & 93 \\
\hline $1.7 \times 10^{9}$ & & 2 & 11 & 0 & 89 \\
\hline
\end{tabular}

surface-disinfected eggs (100 per group), the rate of successful surface sterilization ranged from $84 \%$ to $95 \%$. Surface-sterile eggs were deemed fit for intraovum sampling because the risk of contaminating egg content samples with surface-borne bacteria was nonexistent. Significantly, the only bacteria surviving the egg surface disinfection procedure were fast-growing (unidentified) species. Viable Rs was not found on the surface of the disinfected eggs. Thus, the presence of Rs in smolts derived from eggs used in our 2 experiments (see later) must be accounted for by intra-ovum bacterium.

The hatch success of the various groups of eggs used in the 2 experiments are indicated in Table 2. Hatch rates were higher ( 70 to $85 \%$ ) in those eggs that were not subjected to the handling procedures involved in attempting to infect them with Rs, i.e., the eggs used in the second experiment. Not surprisingly, eggs in the first experiment, which experienced the Rs challenge procedure exhibited lower hatch rates (38 to $62 \%$ ). Notwithstanding this, and as will be shown later, enough Rs-challenged eggs hatched to permit comparisons of the effect of the challenge level on the rate of Rs infections in the resulting smolts.

Table 2. Renibacterium salmoninarum. Hatching success of eggs challenged with various concentrations of Rs. Eggs were immersed in ovarian fluid inoculated with a calculated number of Rs cells $\mathrm{ml}^{-1}$ ovarian fluid (based on a MF-IFAT count made on the Rs cell suspension used to inoculate the ovarian fluid). Spawner: 2 replicate groups of eggs from each Rs challenge level were combined and incubated to hatching in trays according to the challenge received. In addition, eggs from individual Spawners 1 to 5 were incubated in trays according to spawner Actual nos. of Rs cells $\mathrm{ml}^{-1}$ in ovarian fluid were determined using MF-IFAT

\begin{tabular}{|c|c|c|c|c|c|}
\hline Lot & $\begin{array}{l}\text { Calculated } \\
\text { Rs cells } \\
\mathrm{ml}^{-1}\end{array}$ & Spawner & $\begin{array}{c}\text { Actual } \\
\text { Rs cells } \\
\mathrm{ml}^{-1}\end{array}$ & $\begin{array}{c}\text { No. fry } \\
\text { hatched/ } \\
\text { no. eggs } \\
\text { incubated }\end{array}$ & $\begin{array}{l}\text { Eggs } \\
\text { hat- } \\
\text { ched } \\
(\%)\end{array}$ \\
\hline & None & 1 & 0 & $105 / 149$ & 70 \\
\hline & None & 2 & 0 & $119 / 150$ & 79 \\
\hline & None & 3 & 28 & $132 / 155$ & 85 \\
\hline & None & 4 & 56 & $120 / 152$ & 79 \\
\hline & None & 5 & 113 & $115 / 148$ & 77 \\
\hline \multirow[t]{5}{*}{ I } & None & 1-5: pooled & 28 & $159 / 256$ & 62 \\
\hline & $1.7 \times 10^{3}$ & $1-5$, pooled & $1.8 \times 10^{3}$ & $117 / 248$ & 47 \\
\hline & $1.7 \times 10^{5}$ & 1-5, pooled & $2.0 \times 10^{5}$ & $101 / 220$ & 46 \\
\hline & $1.7 \times 10^{7}$ & 1-5, pooled & $1.9 \times 10^{7}$ & $108 / 261$ & 41 \\
\hline & $1.7 \times 10^{9}$ & $1-5$, pooled & $2.1 \times 10^{9}$ & $105 / 245$ & 43 \\
\hline \multirow[t]{5}{*}{ II } & None & $6-10$, pooled & 56 & $108 / 285$ & 38 \\
\hline & $1.7 \times 10^{3}$ & $6-10$, pooled & $2.0 \times 10^{-3}$ & $142 / 270$ & 53 \\
\hline & $1.7 \times 10^{5}$ & $6-10$, pooled & $1.6 \times 10^{5}$ & $112 / 291$ & 39 \\
\hline & $1.7 \times 10^{7}$ & $6-10$, pooled & $1.5 \times 10^{7}$ & $129 / 235$ & 55 \\
\hline & $1.7 \times 10^{9}$ & $6-10$, pooled & $1.9 \times 10^{9}$ & $109 / 231$ & 47 \\
\hline
\end{tabular}


Table 3 summarizes the consequences of incubating eggs in ovarian fluid containing various concentrations of Rs cells. As expected, eggs incubated in Rs-free ovarian fluid proved to be free of intra-ovum Rs (none of the 37 pooled egg content samples tested were infected), indicating that if natural Rs infections occurred in the eggs used in these experiments the infections must have been rare occurrences. No intra-ovum infections occurred when eggs were exposed to $1.7 \times 10^{3}$ Rs cells $\mathrm{ml}^{-1}$ of ovarian fluid, but intra-ovum infections did occur (one in 35 or 36 egg pools) when $1.7 \times 10^{5}$ or $1.7 \times 10^{7} \mathrm{Rs}$ cells $\mathrm{ml}^{-1}$ were present. The prevalence of intra-ovum infections was highest ( 8 of 36 egg pools) in eggs exposed to Rs cell concentrations of $1.7 \times 10^{9}$ $\mathrm{ml}^{-1}$, a result consistent with that obtained by Evelyn et al. (1986a) and one that simulates the situation found in nature where egg infections were always found in fish with ovarian fluid containing $10^{9}$ or more Rs cells $\mathrm{ml}^{-1}$ (Evelyn et al. 1984a, b, 1986b). Unfortunately, precise information on the prevalence of intra-ovum infections

Table 3. Renibacterium salmoninarum. Effect of incubating non-water-hardened, unfertilized eggs in ovarian fluid containing various concentrations of Rs cells on the prevalence of intraovum (Rs) as judged from pooled egg content samples. Eggs immersed in ovarian fluid inoculated with number Rs cells $\mathrm{ml}^{-1}$. Eggs: no surface-sterile eggs tested; Rs-infected eggs/no. tested: number of pooled. Egg contents (10, rarely 5 to 14 eggs) infected by Rs - detected, following enrichment by culture, by IFAT and cultural examinations of the particulate fraction present in the samples (details in text) - per number tested

\begin{tabular}{|c|c|c|c|c|}
\hline Rs cells $\mathrm{ml}^{-1}$ & Lot & $\begin{array}{l}\text { Repli- } \\
\text { cate }\end{array}$ & Eggs & $\begin{array}{c}\text { Rs-infected } \\
\text { eggs/no. } \\
\text { tested }\end{array}$ \\
\hline 0 & \multirow[t]{2}{*}{ I } & 1 & 92 & $0 / 9$ \\
\hline 0 & & 2 & 89 & $0 / 9$ \\
\hline 0 & \multirow[t]{2}{*}{ II } & 1 & 93 & $0 / 9$ \\
\hline 0 & & 2 & 95 & $0 / 10$ \\
\hline $1.7 \times 10^{3}$ & \multirow[t]{2}{*}{ I } & 1 & 90 & $0 / 9$ \\
\hline $1.7 \times 10^{3}$ & & 2 & 89 & $0 / 9$ \\
\hline $1.7 \times 10^{3}$ & \multirow[t]{2}{*}{ II } & 1 & 88 & $0 / 9$ \\
\hline $1.7 \times 10^{3}$ & & 2 & 85 & $0 / 9$ \\
\hline $1.7 \times 10^{5}$ & \multirow[t]{2}{*}{ I } & 1 & 91 & $0 / 9$ \\
\hline $1.7 \times 10^{j}$ & & 2 & 84 & $0 / 8$ \\
\hline $1.7 \times 10^{5}$ & \multirow[t]{2}{*}{ II } & 1 & 93 & $1 / 9$ \\
\hline $1.7 \times 10^{5}$ & & 2 & 87 & $0 / 9$ \\
\hline $1.7 \times 10^{7}$ & \multirow[t]{2}{*}{ I } & 1 & 92 & $1 / 9$ \\
\hline $1.7 \times 10^{7}$ & & 2 & 88 & $0 / 9$ \\
\hline $1.7 \times 10^{7}$ & \multirow[t]{2}{*}{ II } & 1 & 89 & $0 / 9$ \\
\hline $1.7 \times 10^{7}$ & & 2 & 91 & $0 / 9$ \\
\hline $1.7 \times 10^{9}$ & \multirow[t]{2}{*}{ I } & 1 & 86 & $0 / 9$ \\
\hline $1.7 \times 10^{9}$ & & 2 & 91 & $1 / 9$ \\
\hline $1.7 \times 10^{9}$ & \multirow[t]{2}{*}{ I[ } & 1 & 93 & $2 / 9$ \\
\hline $1.7 \times 10^{9}$ & & 2 & 89 & $5 / 9$ \\
\hline
\end{tabular}

is not available because pooled samples were used to reduce the number of egg samples that had to be assayed.

Table 4 records the findings of the first experiment in which smolts resulting from eggs exposed to various levels of Rs were monitored for BKD and Rs. None of the smolts developed clinical signs of BKD and none, of the few specimens that died and were examined within the last 2 mo of rearing, were infected with Rs. The groups of smolts resulting from the experimentally challenged groups of eggs were infected with Rs, indicating that vertical transmission of Rs had occurred. This held true even for the group that appeared to be uninfected following exposure to the lowest challenge level $\left(1.7 \times 10^{3} \mathrm{Rs}\right.$ cell $\left.\mathrm{ml}^{-1}\right)$, suggesting that some intra-ovum infections must, after ali, have resuited frum this challenge. The prevalence of infection in smolts may have been inflated because of the possibility of cross-infections during the $195 \mathrm{~d}$ rearing period. Notwithstanding this, the conclusion that vertical transmission had occurred is supported by the fact that the prevalence of infection tended to show a trend: smolts derived from eggs exposed to the lowest challenge

Table 4. Renibacterium salmoninarum. Determination of Rs prevalence in $195 \mathrm{~d}$-old smolts derived from eggs exposed to various dosage levels of the pathogen in ovarian fluid. Prior to experimental exposure to Rs, the non-water-hardened eggs in Lots 1 and 2 were drained of ovarian fluid and then reimmersed in the clarified fluid (controls) or in fluid inoculated with various dosages of Rs. Exposure was conducted at 4 to $5^{\circ} \mathrm{C}$ with slow shaking for $12 \mathrm{~h}$. Eggs were then dry-fertilized with Rs-free milt (pooled from 3 healthy fish. Actual Rs cell concentrations varied slightly from the expected values (see Table 2). Also, eggs in Lots I and II were inadvertently exposed to ovarian fluid containing 28 and 56 Rs cells $\mathrm{ml}^{-1}$. respectively, prior clarification of the fluid because one or more of the spawners carried Rs in their ovarian fluid. Rs infected smolts were detected using kidney samples and a modification of the MF-IFAT (see text). Dead fish were collected in the $62 \mathrm{~d}$ period prior to sampling

\begin{tabular}{|cccccc|}
\hline Treatment & Rs conc. & Lot & $\begin{array}{c}\text { Spaw- } \\
\text { ners }\end{array}$ & $\begin{array}{c}\text { Infected } \\
\text { smolts/100 } \\
\text { tested }\end{array}$ & $\begin{array}{c}\text { Deadin- } \\
\text { fected } \\
\text { smolts/dead } \\
\text { smolts } \\
\text { collected }\end{array}$ \\
\hline ControI & 0 & I & $1-5$ & 1 & $0 / 0$ \\
& 0 & II & $6-10$ & 3 & $0 / 5$ \\
Inoculated & $1.7 \times 10^{3}$ & I & $1-5$ & 10 & $0 / 0$ \\
& $1.7 \times 10^{5}$ & II & $6-10$ & 8 & $0 / 0$ \\
& I & $1-5$ & 20 & $0 / 1$ \\
& $1.7 \times 10^{7}$ & II & $6-10$ & 9 & $0 / 4$ \\
& $1.7 \times 10^{4}$ & II & $1-5$ & 15 & $0 / 2$ \\
& & II & $1-5$ & 29 & $0 / 0$ \\
& & & $6-10$ & 24 & $0 / 2$ \\
\hline
\end{tabular}


level of Rs showed lower infection rates ( 8 to $10 \%$ ) than those derived from the most severely challenged eggs (24 to $44 \%$ ).

Of particular interest was the fact that smolts derived from eggs not experimentally exposed to Rs were also infected. The prevalence of infection in these smolts was low (1 to $3 \%$ ) and, again, may have been inflated by cross-infections during the smolts' $195 \mathrm{~d}$ rearing period. The presence of infection in these fish was, however, significant because smolts were derived from pooled eggs held in pooled ovarian fluid that, prior to clarification, contained very low concentrations of Rs cells (28 and 56 Rs cells $\mathrm{ml}^{-1}$ of fluid for Lots I and II, respectively). The source of $\mathrm{Rs}$ cells in the pooled (unclarified) ovarian fluid of Lots I and II was obviously one or more of the seemingly healthy spawners that provided the eggs and ovarian fluid for the lots. Data relating to this, for the 5 spawners of Lot I are given in Table 5 . It can be seen that 2 of the 5 spawners yielded Rs-free ovarian fluid and Rs-free smolts. The other 3 spawners, however, produced ovarian fluid containing low concentrations of Rs cells ( 28 to $113 \mathrm{ml}^{-1}$ ), and 1 to $2 \%$ of their progeny carried subclinical Rs infections.

The question to be answered is how the low levels of Rs cells in the ovarian fluid of the foregoing spawners resulted in infected progeny, particularly since it has not been possible in this and one other study (Evelyn et al. 1986a) to establish egg infections using higher concentrations of Rs cells (e.g. ca $10^{3}$ Rs cells $\mathrm{ml}^{-1}$ ). One possibility is that intra-ovum infections also occur directly from infected ovarian tissue prior to ovulation. Data suggesting that this may sometimes occur have already been reported (Lee \& Gordon 1987a). Another possibility is that the infections came from the ovarian

Table 5. Renibacterium salmoninarum. Rs prevalence in offspring of 5 spawners in Lot 1. Spawners: eggs (not experimentally exposed to Rs), obtained from each of the 5 spawners, were fertilized with Rs-free milt. Eggs from each fish were incubated separately and the resulting progeny were reared in separate tanks to the smolt stage. Rs concentration in the ovarian fluid was determined using MF-IFAT and Rs infections detected using kidney samples and a modification of MF-IFAT (see text). Dead fish were collected in the $62 \mathrm{~d}$ period prior to sampling

\begin{tabular}{|cccc|}
\hline Spawner & Rs cells $\mathrm{ml}^{-1}$ & $\begin{array}{c}\text { Infected } \\
\text { smolts/100 } \\
\text { tested }\end{array}$ & $\begin{array}{c}\text { Dead infected } \\
\text { smolts/dead } \\
\text { smolts } \\
\text { collected }\end{array}$ \\
\hline 1 & 0 & 0 & $0 / 0$ \\
2 & 0 & 0 & $0 / 1$ \\
3 & 28 & 1 & $0 / 0$ \\
4 & 56 & 1 & $0 / 2$ \\
5 & 113 & 2 & $0 / 4$ \\
\hline
\end{tabular}

fluid but that non-homogeneous distribution of the bacterium in the fluid occurs, resulting in 'hot spots' of infection for eggs - 'hot spots' that are not readily apparent using current ovarian fluid sampling methods. Both possibilities are now being investigated.

In summary, the present findings confirm that vertical transmission occurs as a result of intra-ovum infections and that such infections are likely to be most frequent when eggs are exposed to heavily infected ovarian fluid. The results also show that Rs infections in smolts are most frequent when smolts are derived from eggs exposed to ovarian fluid containing high Rs concentrations. Disconcertingly, however, low level infection in ovarian fluid also resulted in vertical transmission of Rs. These low level infections would almost certainly have gone undetected using the IFAT procedure routinely used in the aforementioned broodstock anti-BKD screening program, perhaps explaining why the broodstock screening program in B.C. has not been successful in producing Rs-free smolts for fish farmers. Clearly, a more sensitive anti-BKD screening procedure is needed and a better understanding of how eggs acquire their infections is required.

Acknowledgements. The authors thank R. J. Gawley, I M. Vo, D. Bradley, and R. Loy for their capable technical assistance and the B.C. Ministry of Agriculture and Fisheries, the Department of Fisheries and Oceans, and Supply and Services of Canada for financial support of this study.

\section{LITERATURE CITED}

Armstrong, R. D., Martin, S. W., Evelyn, T P. T., Hicks, B., Dorward, W. D., Ferguson, H. W. (1989). A field evaluation of an IFAT-based broodstock screening test used to control the vertical transmission of Renibacterium salmoninarum in chinook salmon (Oncorhynchus tshawytscha). Can. J. Vet. Res. (in press)

Beli, G. R., Higgs, D. A., Traxler, G. S. (1984). The effect of dietary ascorbate, zinc, and manganese on the development of experimentally induced bacterial kidney disease in sockeye salmon (Oncorhynchus nerka). Aquaculture, Amsterdam 36: 293-311

Bullock, G. L. Stuckey, H. M., Mulcahy, D. (1978). Corynebacterial kidney disease: egg transmission following iodophor disinfection. Fish Fealth News 7: 51-52

Elliott, D. G., Barila, T Y. (1987). Membrane filtration-fluorescent antibody staining procedure for detecting and quantifying Renibacterium salmoninarum in coelomic fluid of chinook salmon (Oncorhynchus tshawytscha). Can. J. Fish. aquat. Sciences 44: 206-210

Evelyn, T. P. T. (1977). An improved growth medium for the kidney disease bacterium and some notes on using the medium. Bull. Off. Int. Epitzoot. 87: 511-513

Evelyn, T P. T., Ketcheson, J. E., Prosperi-Porta, L. (1984a). Further evidence for the presence of Renibacterium salmoninarum in salmonid eggs and for the failure of povidone-iodine to reduce the intra-ovum infection rate in water-hardened eggs. J. Fish Dis. 7: 173-182 
Evelyn, T. P. T., Prosper1-Porta, L., Ketcheson, J. E. (1984b). The salmonid egg as a vector of the kidney disease bacterium, Renibacterium salmoninarum. In: ACUIGRUP (ed.) Fish Diseases, 4th COPRAQ Session. Editora ATP, Madnd, Spain, p. 111-117

Evelyn, T. P. T., Prosperi-Porta, L., Ketcheson, J. E. (1986a). Experimental intra-ovum infection of salmonid eggs with Renibacterium salmoninarum and vertical transmission of the pathogen with such eggs despite their treatment with erythromycin. Dis. aquat. Org. 1: 197-202

Evelyn, T P. T., Prosperi-Porta, L., Ketcheson, J. E. (1986b). Persistence of the kidney disease bacterium, Renibacterium salmoninarum, in coho salmon, Oncorhynchus kisutch (Walbaum), eggs treated during and after waterhardening with povidone-iodine. J. Fish Dis. 9: 461-464

Lee, E. G.-H. (1986). On-site screening of bacterial kidney disease (BKD) in salmon broodstock. Marine Resources,

Editorial responsıblity: Vanaging Editor
Fisheries Branch, Ministry of Environment, Victoria, B.C., Canada, V8V $1 \times 4$

Lee, E. G-H. (1989). Technique for enumeration of Renibacterium salmoninarum in fish kidney tissue. J. aquat. anim. Health 1: 25-28

Lee, E. G.-H., Gordon, M. R. (1987a). Immunofluorescence screening of Renibacterium salmoninarum in the tissues and eggs of farmed chinook salinon spawners. Aquaculture, Amsterdam 65: 7-14

Lee, E. G.-H., Gordon, M. R. (1987b). Development of a quantitative threshold dosage of Renibacterium salmoninarum in ovarian fluid which causes egg infection. Ministry of Agriculture and Fisheries, Victoria, B.C., Canada, V8V $1 \times 4$

Mitchum, D. L., Sherman, L. E. (1981). Transmission of bacterial kidney disease from wild to stocked hatchery trout Can. J. Fish. aquat. Sciences 38: 54.7-551

Manuscript first receivod: July 14, 1989

Revised version accepted: September 22, 1989 